with much of what has prevailed in urban studies, as reflected, for instance, in his 1966 article, "Are We a Nation of Cities?" which was published in The Public Interest. Dan focused more on the fact that the predominant form of urban settlement in the United States has been the small and medium-sized city, not the big cities that occupy so much academic attention. He was, therefore, an early observer of suburbanization as well, though never critical of it in the manner of so many social scientists. Likewise, while recognizing the problems created by a multiplicity of governments in metropolitan areas, he did not advocate metropolitan governmental consolidation or even formal federal structures for metropolitan areas; instead, he argued that public policy should support and foster the civil community responses to metropolitanization already evident on the prairie and elsewhere.

One of Dan's earlier imaginative and fascinating essays is "Urbanism and Federalism in the United States," published in hearings before the Joint Economic Committee of the U.S. Congress in 1967. There, he argued that one key to understanding urban life in the United States is that Americans patterned their cities more after their conceptions of biblical models with their agrarian elements than after their experiences with European models of "citified" urban life surrounded by peasants; consequently, successful prescriptions for urban ills would have to resonate with Americans' distinctive notions of city life.

Dan's work on Jewish political studies and community life was also prodigious. His Community and Polity: The Organizational Dynamics of American Jewry (1976), often referred to as the "Bible of Jewish communal service," quickly became a classic and was reissued in a revised version in 1995 by the Jewish Publication Society. Rabbi Michael A. Monson, as publisher and executive vice president of JPS, joked with Dan, saying that he had had the privilege of publishing two Bibles: God's and Dan's. Dan also took the Hebrew Bible seriously as a political scientist, not only as an in- fluence on early modern Western political thought and on the American founding but also as a work of political theory in its own right. $\mathrm{He}$ sought to uncover parts of this theory in his 1980 monograph, The Book of Joshua as a Political Classic: A Commentary. Dan also argued, controversially, that Jews have a continuous political tradition that extends back to biblical days, that a people can have polity without a state, and that Jews, in fact, have a portable polity-the Edah.

Dan would probably regard as his culminating synthetic work four recent volumes published under the general title "The Covenant Tradition in Politics": Covenant \& Polity in Biblical Israel: Biblical Foundations and Jewish Expressions (1995); Covenant and Commonwealth: From Christian Separation Through the Protestant Reformation (1996); Covenant \& Constitutionalism: The Great Frontier and the Matrix of Federal Democracy (1998); and Covenant and Civil Society: The Constitutional Matrix of Modern Democracy (1998). Here, he traced the history and permutations of the covenant idea from the Bible to today, seeing as especially important the revival of the covenant idea through the covenant or federal theology of Reformed Protestantism in the sixteenth century. Again, there is an emphasis on continuity of an ancient idea throughout revolutionary change and, for Dan, on the fundamentals of federalism; namely, chesed (covenantal love) and arevut (interdependence and mutual responsibility) among the b'nai berit (partners to the covenant or federal union).

One cannot reflect on Dan's life without also remarking upon his remarkable ability to render his physical disability irrelevant to the extraordinary vigor of his mind, vitality of his soul, and endurance of energy. Having contracted polio as an adolescent, he lived with its gradually debilitating effects, walking with a cane during his younger years, then with two canes, and then needing a wheelchair constantly for mobility. Deciding to purchase his own wheelchair was the only time I ever detected a note of defeat in his voice.
Traveling with Dan, and he traveled virtually everywhere in the world many times, was an eye-opening experience-often traversing a restaurant or hotel kitchen to reach a dining table or meeting room, entering buildings at the rear or through a cargo area, riding freight elevators, soothing an embarrassed host who had organized an event at a place inaccessible for Dan, learning too late that what facility managers defined as "handicapped accessible" was not always accessible for Dan, and negotiating for nearly two hours with authorities at a Brazilian airport until they mobilized a huge cargo lift to remove Dan from his aircraft. Yet, one could also see that legislation can make a difference; access became easier and more widely available by the 1990 s, especially in North America, at a time, moreover, when Dan needed easier access.

When asked by Neal Riemer of Drew University, "What accounts for your immensely productive career?" Dan answered, "I rest on Shabbat." It is to be wished that he were resting only for the seventh day, but the fruits of his life and work offer enduring sustenance. May Daniel J. Elazar's memory in eternal rest, therefore, be for a blessing. John Kincaid Lafayette College

\section{Daniel Elazar: A Reflection}

In the realm of scholarship, Daniel Elazar is one of those individuals who will always remain with us even after he ceased to be a mortal being. I know that I shall never again share the long discussions with Dan, which we had wherever we might meet at many places in this world. What remains with me is the way that I as a political scientist have come to think about the constitution of order in human societies and what it means to become selfgoverning in democratic societies. Dan will always be a part of how those thoughts have come to have meaning for me and others.

As one who had begun to ponder the meaning of federalism viewed from the bottom up, it was my good fortune to have been invited to join 
the various working groups that Dan brought together to explore the idea of covenant as the core concept that captured the spirit of federalism. The standard preoccupation with federal forms of government is devoid of the spirit that enables ordinary mortals to exercise their creative potentials as they adapt to changing conditions in the exigencies of life.

Dan often called attention to the linguistic tie between covenant and federalism as reflected in the Latin root foedus as the foundation for terms such as "federal," "federalism," and "confederation." It was learning about this linguistic root that enabled me to understand why Alexander Hamilton, John Jay, and James Madison would call their essays on the draft constitution of 1787 The Federalist and why Alexander Hamilton's essays on meaning had their significance.

As Dan always emphasized, the root-term "covenant" (foedus, b'rit) lay at the foundation of Jewish, Christian, and Islamic teachings and the meaning of those teachings to the emergence of human civilizations. These teachings are foundational in the sense that they provide a method of normative inquiry and the ontological foundations of human understanding. Basic precepts expressed as commandments of "Do unto others as you would have others do unto you," "Love thy neighbor as thyself," and "Honor God above all else" stand at the foundations for moral community among communities of artisans who see their own creativity as doing honor to the Creator and His Creation. The point that Dan always emphasized was accessibility of the meaning of basic precepts associated with the core concept of covenant without becoming preoccupied with theological disputation. The commandments of Jewish, Christian, and Islamic traditions imply an empire of laws and not of men. On the basis of these precepts, we can then understand the place of peace, justice, and liberty as universal goods, which increase in value as they are more widely shared and allow for creativity to ameliorate the conditions of scarcity that plague those who treat the nature of the Creator's Creation as a bonanza to be freely exploited. The teachings of Moses, Jesus of Nazareth, Muham$\mathrm{mad}$, and the other prophets provide us with continuities for building federal (covenantal) societies in which federal forms structure due processes by which peoples can construct covenantal cultures, societies, and civilizations.

These are the meanings that Dan illuminated for those of us who shared discussions with him. His central preoccupation as a political scientist was with rule-ordered relationships, but the discussions of covenantal systems of order always required collegial participation among philosophers, theologians, students of jurisprudence, historians, and interested social scientists. The discourse was thoroughly republican in the sense of being a part of an open public realm.

For me, Dan's concern with the foundational character of covenanting and the covenantal nicely complemented and illuminated the importance of James Buchanan and Gordon Tullock's foundational work in The Calculus of Consent. Constitutional choice as a reiterative process, applicable to all different forms of enduring human associations requiring recourse to collective action, enables us to take explicit account of what might be called the principles of natural justice and how these might be expressed in ways that are appropriate to specific contexts and shared communities of understanding. A covenantal approach to constitutional choice is more enlightening to me than what is called "a contractarian approach." Patterns of reciprocity and trust reach deeper than quid pro quo relationships.

Emphasis on the foundational character of covenanting and the covenantal gives new meaning to Alexis de Tocqueville's Democracy in America as a part of the longterm movement in a democratic revolution reaching back to the beginning of the second millennium. Tocqueville's analysis gave expression to what Larry Siedentop has referred to as a "self-governing" society that had emerged in North America in contrast to the European conception of "state-governed" societies.

Puritan congregations and New England townships provided, as Tocqueville recognized, the germ, the core concept, that gave meaning to all that followed, including the federal constitution of the United States of America. I now understand why Tocqueville considered religion to be "the first of their political institutions" even though it takes "no direct part in the government of society." He turned to the mores of the people as the most important factor contributing to the maintenance of democracy. The practice of covenantal theology shapes the moral community of their hearts and the ontological foundations of their thinking. The principal threat to American democracy would arise as successive generations of Americans might fail to reproduce a covenantal way of thinking and the maintenance of covenantal relationships with one another in self-governing communities of relationships. They might, for example, turn to "the Government" to solve all of their problems. In that case, democracy would, to use a Marxist term, "wither away."

In the closing decades of the twentieth century, we can thank Daniel Elazar for our understanding of how covenanting and covenantal relationships provide the key to understanding the spirit that drives federal forms, gives meaning to constitutional formulations, and a base for both a due process of law and a due process of inquiry. It is important that we as political scientists learn the lessons that Daniel Elazar had to teach and extend those teachings to form the foundations for civic education. Dan's heritage will remain with us, giving meaning to democracy and an awareness of the vulnerability of democracies.

Vincent Ostrom Indiana University 